\title{
FbG as an around the clock support for an essay writing course amidst the pandemic
}

\section{Tono Suwartono*}

English Language Teaching (ELT) Department, Faculty of Teacher Training, Universitas Muhammadiyah Purwokerto, Central Java, Indonesia

\author{
*Correspondence \\ Email: suwartononewton@gmail.com
}

\author{
Received: \\ Revised: \\ Accepted: \\ Published: \\ 14 March 2021 \\ 16 July 2021 \\ 1 August 2021 \\ 31 August 2021
}

\begin{abstract}
This study aimed to explore the potential of Facebook Group (FbG) for teaching essay writing skills in the period of social distancing due to covid19 pandemic. The study involved three groups of students who had been attending Essay Writing Course. Data was collected through questionnaires, interview, home assignments, and documents. Questionnaires were distributed via Google Form. Interviews were conducted with students through WhatsApp chats and calls. Descriptive statistics were used to analyse data obtained from closed questionnaires, home assignments, and mid-term test. Data from open questionnaires, interviews, and documents was analysed using qualitative inductive approach to identifying themes topics, ideas, and patters of meaning. Study findings indicated that FbG has been an appropriate place for developing essay writing skills amidst the pandemic. FbG as networking site has made possible an effective, efficient, and practical essay writing learning for the following reasons. Firstly, FbG discussion forum provided invaluable learning input. Secondly, FbG was easy to operate. The students could learn independently at their own pace. Lastly, use of FbG brought them convenience and raised confidence to better engage in learning online. FbG has supported students' essay writing learning process that has led to good writing performance. This can be seen not only from the conducive learning process in comparison to traditional classroom instruction prior to the pandemic, but also from learning outcome apparently observed in writing portfolios as well as mid-term test.
\end{abstract}

Keywords: Facebook group; online essay writing

\section{INTRODUCTION}

Covid-19 outbreak has affected many sectors of life, including educational systems worldwide. In Indonesia, the lives of millions of children and young adults have already been upended. Some restrictions and school, university, and college closures are affecting their education. With half the school year yet to go, nearly all educational institutions reached out to offer those students online learning. 
Suwartono. (2021). FbG as an around the clock support for an essay writing course amidst the pandemic. EduLite: Journal of English Education, Literature, and Culture, 6 (2), 238-255. http://dx.doi.org/10.30659/e.6.2.238-255

In difficult circumstances for teaching and learning, for teachers and students, accessibility matters more than ever. According to Circular Letter No. 3 Year 2020 - about Covid-19 prevention within educational units - issued by The Ministry of Education and Culture of Indonesia, all higher educations in the Republic of Indonesia are required to implement instructions through online media. Online education takes computers (desktops, laptops, or smartphones) connected to the internet. Application software is also needed in order to operate the system. With these online media, despite social distancing, teaching can go on concurrently with learning in the part of students. A recent study of online learning conducted in its attempt to deal with educational challenges during the COVID-19 pandemic claimed that distance learning, to some extent, gives outcomes similar to those expected from face-to-face teaching (Jacques et al., 2020).

Choice of online instructional media is unlimited, including social media and online platforms. Nowadays, there have been many, some of which have drawn the attention of researchers and experts to study with respect to their contribution to education. WhatsApp, Google Classroom, Online Class, Schoology, Zoom, Instagram, and Facebook are among others. A survey on social media usage in English language teaching in Hong Kong showed that WhatsApp and Facebook were identified as two most favourite "unofficial" (informal) learning support media, while YouTube and Wikis were found to be two most frequently used "official" learning media tools (Li, 2017). Whichever platform a teacher prefers to utilize, thorough and thoughtful prior consideration is a must. With the challenging personalities of being creative and innovative a teacher is supposed to take the one which most probably gives maximum contribution to student learning.

As of April 9th, 2020, Facebook has the world's largest number of users among the existing social media, with 2.5 billion people (Kallas, 2019). In Indonesia, according to GobalStats (2020), Facebook takes the first position in audience size, with $49.73 \%$ of total users across social network sites. Therefore, at present, Facebook is the most popular social network site. Research on Facebook emanates from a wide variety of disciplines. One study investigated the impact of Twitter and Facebook on learning about the news (Boukes, 2019), where it was nicely reported that in the topic of politics Facebook had negative impact on learning, due to the existing gap between politically interested and uninterested citizens. A study by Ngai (2019) revealed that Facebook has developed Japanese students' transnational competence. Facebook turned out to help first year university students with social, institutional as well as emotional adjustment to higher education life (Wope \& Belle, 2018).

Research on Facebook has shown that Facebook could be made to successfully assist learning, even though it was regarded as informal learning media (Toker \& Baturay, 2019). Experts have proposed the educational potential of Facebook. Manca and Ranieri (2014) argued that Facebook has technical and educational affordances. From technical point of view, it is easy to use, accessible, and intuitive. From pedagogical perspective, at least it offers socialization, communication, and community building, sharing of resources and genuine materials, social learning and collaborative activities, as well as a mix of formal and informal learning. In Thailand, Facebook has been utilized 
by the English instructors to help themselves learn. The use of Facebook in the English teachers' professional development has given positive impact on their English writing skills and learning attributes (Sirivedin et al., 2018). This social network site has the potential to be utilized in teaching and learning. Experimental research on Facebook aimed to enhance student participation in learning English has confirmed effective (Syafrial et al., 2019). A survey study of similar area of interest has shown consistent results (Saddhono et al., 2019). A study of foreign students in an Indonesian state university has also claimed that the informal atmosphere of Facebook enabled the foreign students to subconsciously absorb the materials that had been mounted to the Facebook page by the teacher. As an essay writing course teacher at university, the author has long had interest in empowering Facebook for helping his students attain the skills and knowledge. The passion has become even stronger when the pandemic struck.

Some research on teaching writing using Facebook has reported that Facebook was able to improve student writing skill (see, e.g., Ramadhani, 2018; Imaniah, 2020). According to the research, it was made possible because of one of its strengths, namely 'Comment' space. With the space students interacted with one another and responded their writing. By doing so, students had opportunity to develop their English writing skill. Use of Facebook was also reported to help students with what and how to write in academic writing (Sulisworo et al., 2016). It was good news, in that so far, students have found it hard to get started to write. One obvious difference between the research and the current project is that the former used Facebook as a whole with more open heterogeneous membership, while the latter, as its name suggests, is a private group with a limited homogeneous community membership. Another side which distinguishes the present research study from the one discussed earlier is that the former research investigated writing skill in general, while this current research focused on essay writing.

What makes Facebook a greater potential for educational context is the Facebook group (henceforth abbreviated as "FbG") inside it, which has characteristics truly compatible with educational setting. Kent (2014) mentioned at least eight features $\mathrm{FbG}$ has that enable a more authentic community of learning. FbG can be set to 'closed' or 'private'. Only those members of the particular group can take part in it. It provides a real-time interaction, even much faster than email. FbG is superior in terms of communication and discussion. This networking site stores information and resources posted to it. Level of engagement is high for participants, due to ease of access and practicality (for instance, single login). It encourages information exchange. Certain facilities support genuine communication, for example 'seen by' to make sure if a post is received or not. Besides, FbG as part of Facebook, provides an always-on communication.

In language teaching, a study examining the benefits of $\mathrm{FbG}$ has founded that the use of $\mathrm{FbG}$ in language classrooms had positive effect on individual's affective domain (Andini, 2019; Hamidah \& Yanuarmawan, 2017; Tananuraksakul, 2015). According to the reports, it was made possible with the features it offers (e.g., 'like') and the atmosphere it creates (e.g., sense of relaxation and lowering of anxiety). It also had an attitudinal impact (Friatin, 2018). Some research on FbG claimed that it has helped students learn to 
Suwartono. (2021). FbG as an around the clock support for an essay writing course amidst the pandemic. EduLite: Journal of English Education, Literature, and Culture, 6 (2), 238-255. http://dx.doi.org/10.30659/e.6.2.238-255

write (Aziz \& Khatimah, 2019; Ping \& Maniam, 2015; Yunus, Salehi et al., 2011). Specifically, in essay writing, it facilitated writing in the pre-teaching stage of brainstorming, prior to actual essay writing activity. In addition, $\mathrm{FbG}$ has helped students get accustomed to topic setting, develop better thinking, share ideas and mind mapping, reduce misspelling, and find new vocabulary (Alotumi, 2015). The students' response reflected positive attitudes towards FbG usage in instruction, as they felt convenient, encouraged and prepared to write after they joined FbG. Journal dialog through closed FbG has not only improved student writing skill, but also helped them express themselves in a better way, interact with peers and teacher more meaningfully, build good relationship among them, and learn from one another (Rodliyah, 2016). Apparently, FbG has had the potential to benefit essay writing teaching and learning online, not only served as a medium of distant communication as it was initially created for.

FbG in the context of this research was considered to serve as a class forum where interaction among members - teacher-student and studentstudent - and between members and learning content can take place. Some benefits had been taken into account regarding FbG usage for the online learning media under the harsh condition of Covid-19 pandemic. In addition to low-cost (and even free of charge when connecting to Wi-Fi), unlimited access time would have been another exciting idea. Since FbG is part of Facebook, the use of $\mathrm{FbG}$ to support learning was valued efficient and practical. As touched on earlier, this type of social media has been popular. Most students were assumed to be familiar and become regular users of it. Once one is connected to Facebook, FbG membership is only one little step ahead, either by asking to join or waiting to be invited. Last but not least, with the features offered compatible to essay writing skill development. It can be said that the use of $\mathrm{FbG}$ in teaching and learning would be promising.

$\mathrm{FbG}$ in the context of the current research was also regarded as a learning environment created by the teacher for the students. In the FbG, many support features are available, such as Discussion, Comment, Reply, Post, Attachment, Edit, Add File, seen by..., Create Event, write post, Create Doc too many to mention. A Discussion, for instance, is basically a menu which comprises features for the group members to have live interaction and communication in real-time. With this space, members can discuss, share ideas, ask and answer questions. Similarly, when utilized for instructional purposes, a teacher and students can take their roles using those "amenities". With Comment, a teacher and or a classmate can provide written messages, inserted or attached items. The written message which was sent by a member via space could be a student's brief instant essay writing or a Google Drive link share. With Reply, a teacher and or students can give response to a written message, inserted or attached items below the target Comment complete with unique emoticons for efficiency. In theory, $\mathrm{FbG}$ should make essay writing learning effective and practical. More specifically, some features are highly relevant with an essay writing development. Let us say, Edit and Post, which are essential part of an essay writing activity, or, Create Doc which is perfectly suitable for an essay writing project. With Create Doc a student can share the essay he/she created with a professional look format along with a space for a photo by simply dragging or clicking one to add. This feature opens the 
opportunity for a kind of author collaboration, where other participants are welcome to edit an essay. It enables students to develop their essay writing skill because, through $\mathrm{FbG}$, online learners generate their own learning content and take the advantage of collective knowledge (Faizi et al., 2013). In addition to collaborative value, it also encourages to build sense of accomplishment.

Those all facilities and possible activities above are a compelling way for students to develop their essay writing skill and are the educator's creative breakthrough in response to the coronavirus pandemic. Therefore, through this study the researcher explored the potential of FbG for teaching essay writing skill during the pandemic.

\section{METHOD \\ Respondents}

This study was carried out in the Department of English Language Teaching at a university in the town of Purwokerto, Central Java Province, Indonesia. It involved 87 students who had been attending Essay Writing Course for a month (4 sessions) when the Covid-19 pandemic outbreak began in the country.

\section{Data collection}

Data were collected through questionnaires, interview, home assignments, and documents (FbG screenshot, writing video screenshot, and mid-term test result). Questionnaire blueprint was prepared to help achieve logical validity. Written in the Indonesian language, the questionnaires consisted of two types: closed questionnaires (items 1, 2, 3, 4, 7) and open questionnaires (items 5, 6, 8). Items 1,2 , and 3 served as guiding questions; item 4 as the key question asking if FbG usage facilitated learning, and item 7 asked whether or not the use of FbG needed to be continued. Item 5 sought details related to item 4 . Item 6 required information on weakness of $\mathrm{FbG}$ instruction. Item 8 needed student feedback. This study focused on data revealed from both questionnaire item numbers 4 and 5. Questionnaires were distributed via Google Form due to the pandemic. The responses and data gathered were automatically saved to a Google spreadsheet in real time.

Interviews were targeted to all respondents through WhatsApp chats (both written chats and or audio chats) and WhatsApp calls to ask those survey questionnaire participants for clarification and fine-tuning, and explore the potential of media online FbG for teaching essay writing. However, only 23 out of 87 participants voluntarily gave response to the invitation for interviews.

\section{Data analysis}

With regard to the data gathered, it was then analysed according to the matters under investigation. Descriptive statistics were used to analyse data obtained from closed questionnaires, home assignments, and mid-term test. Data from open questionnaires, interviews, and documents was analysed using qualitative inductive approach to identifying themes - topics, ideas, and patters of meaning. 
Suwartono. (2021). FbG as an around the clock support for an essay writing course amidst the pandemic. EduLite: Journal of English Education, Literature, and Culture, 6 (2), 238-255.

\section{RESULTS AND DISCUSSION}

From answers to a closed questionnaire item number 4: "Compared to classroom in-person learning prior to the pandemic outbreak, is your Essay Writing online class via Facebook Group now more helpful?" it found that only $28.7 \%$ of the students favoured this online learning using FbG. They chose option 'Yes'. Most students (55.2\%) were in doubt about benefit of employing FbG. They stayed their ground in between, by choosing option 'No idea'. The remaining $16.1 \%$ chose 'No' which indicated that to them FbG gave no significant contribution to their essay writing learning and development. Table 1 displays students' response to significance of $\mathrm{FbG}$ in the essay writing instruction solely according to closed questionnaire.

Table 1. Seemingly cool response to FbG as learning media

\begin{tabular}{lcc}
\hline Response & $\begin{array}{c}\text { No. of } \\
\text { Students }\end{array}$ & $\begin{array}{c}\% \\
\text { of Total }\end{array}$ \\
\hline Beneficial & 25 & 28.7 \\
\hline No idea & 48 & 55.2 \\
\hline Unbeneficial & 14 & 16.1 \\
\hline
\end{tabular}

Indeed, this finding was not as expected at all to reflect a positive response. However, further from the open questionnaires and interview, it turned out that the students favoured the network site FbG applied to their course amidst the pandemic and felt the benefit of it in learning and practicing essay writing.

Based on replies to open questionnaire item number 5: "If you think your essay writing instruction online applying FbG has assisted you to learn and practice, in what way do you think FbG facilitates your learning? Please state briefly but clearly", replies varied greatly. A few did not answer at all and some response remained unclear. Overall, the data fell into five categories of themes. Table 2 shows benefits of FbG usage in the essay writing course according to students.

Table 2. Benefits of FbG usage in essay writing according to students

\begin{tabular}{clcc}
\hline No & \multicolumn{1}{c}{ Benefits } & $\begin{array}{c}\text { No. of } \\
\text { Responses }\end{array}$ & \% of Total \\
\hline $\mathbf{1}$ & $\begin{array}{l}\text { FbG features (discussion, posts, } \\
\text { translation, etc.) helped provide } \\
\text { invaluable learning input }\end{array}$ & 36 & 48.00 \\
& $\begin{array}{l}\text { Virtual participants on FbG brought } \\
\text { convenience and raised confidence to } \\
\text { share ideas / thoughts }\end{array}$ & 12 & 16.00 \\
\hline $\mathbf{2}$ & $\begin{array}{l}\text { FbG content was accessible at any } \\
\text { time anywhere }\end{array}$ & 10 & 13.33 \\
\hline $\mathbf{4}$ & FbG was simple to access or use & 10 & 13.33 \\
\hline $\mathbf{5}$ & Misc. & $\leq 3$ each & 09.34 \\
\hline
\end{tabular}


As can be seen in the table, nearly half of the total number of students reported that they benefited from $\mathrm{FbG}$ usage in the teaching and learning process. All argued $\mathrm{FbG}$ had features that enabled them to learn and practice writing effectively. A student wrote:

"Right, we can read a friend's essay and compare it with our own, and read feedback from friends about strengths and weaknesses of an essay, so that we get insights into how to write a quality essay." (S33)

Such learning is reflective in that students learn by monitoring and evaluating their own performance. FbG features such Post, Comments, Reply, Create Doc, etc. in Discussion menu make it possible for a reflective learning to take place. The statement of student below more explicitly illustrates how reflective learning became part of his/her learning and practice assisted with FbG features:

“...helps me understand step by step feedback, critics, and suggestions that friends wrote in the Comment space while checking my essay again and correcting mistakes, if any." (S27)

That is why, in some replies, students mentioned that they learnt a lot of language components, i.e., grammar and vocabulary from other participants and teacher. Even they learnt punctuation and topic initiative raising._Second most replies referred to the advantage of being away from the crowd. In the absence of friends and teacher in-person in learning online through FbG, students commented that with the online learning platform, FbG students felt like no burden and free to move. A student commented as follows:

"...more courageous to share ideas and ask questions without feeling shy, unlike any face-to-face classrooms." (S21)

The following short statement is also straight to the point:

"...feel confident in commenting on a friend's essay because we are not face to face." (S14)

Two other categories of response themes significant enough to take into account relate to accessibility of FbG, with each $13.13 \%$ of the total. As part of Facebook, FbG is something far from being complicated for the students. Moreover, as a social media network site with the largest number of users in the world and within Indonesia, it is familiar to them, as stated by a student:

"No doubt about it, the features available on Facebook are simple. We all know that people easily gain Facebook technical know-how. Each online session is separated from one another...in such a way that it is not confusing to find a chapter. Besides, I can share links on Facebook Group." (S16)

Once students have internet connection, they can access a site multiple times as they want. Time and space do not matter anymore. With regard to content on FbG, students can return to any materials as resources on it anywhere at any time later and learn at their own pace. This idea is good for learning enhancement. See how a student experienced learning below:

"I am feeling supported in learning with the written conversations and explanations shared there because I understand answers and explanations better, and study them repeatedly to understand even better" (S51) 
Suwartono. (2021). FbG as an around the clock support for an essay writing course amidst the pandemic. EduLite: Journal of English Education, Literature, and Culture, 6 (2), 238-255. http://dx.doi.org/10.30659/e.6.2.238-255

Further investigation through interview has brought to light the students' genuine experience with the applied online learning media. Out of all 87 students invited via Whatsapp chat and call, 23 expressed willingness to be interviewed. Interviews revealed some additional detailed, specific data supporting the investigation of the potential of $\mathrm{FbG}$ for conducting essay writing class online. This was possible because the researcher helped the interviewees understand better and focus on the question. A student stated:

“..., I find it easier and more focused to identify and make correction to friends' essays. Besides, I have become more courageous in giving feedback." (S07)

The comment is, to some extent, clear. It is something psychological. The use of FbG in the essay writing class seemed to psychologically affect students positively. The student felt at ease with the now essay writing teaching and learning online, as compared to the previous face-to-face classroom teaching and learning. When linked to the literature things become clear. In most cases, there has been crisis of confidence to ask and answer questions, students are too shy in the classrooms, they are even afraid to be called "attention seeker" (Suwartono \& Mayaratri, 2011). Therefore, they normally quiet. Without a friend and teacher near them they felt freer to express their aspirations, as spoken explicitly by a student in the following statement:

“...I've become more courageous to share ideas since essay writing class was conducted using Facebook Group because I do not see others in person ...." (S16)

They seemed to feel inconvenient to share ideas, ask or answer questions with friends and teachers around. A few students also said that they took the advantage of not being among friends just because no friends asked to chat with them anymore while having a lesson since then, so that they could concentrate on learning materials and learning activities.

Students have learnt and used English essay writing better since they got involved in the essay writing course online. Some students reported that they gained insights into English essay writing, including new vocabulary, grammatical items, generic structure, and styles and experienced language in use by comparing their own work with friends' and self-correcting it. A student was purposefully or randomly invited to share his or her work on the class FbG, but at times one initiated voluntarily. The work could be either a brief text related to a part rather than the whole essay or a full text assigned the preceding week. Figure 1 displays a screenshot of a sample student's work posted to the FbG page to be discussed by the class participants. 


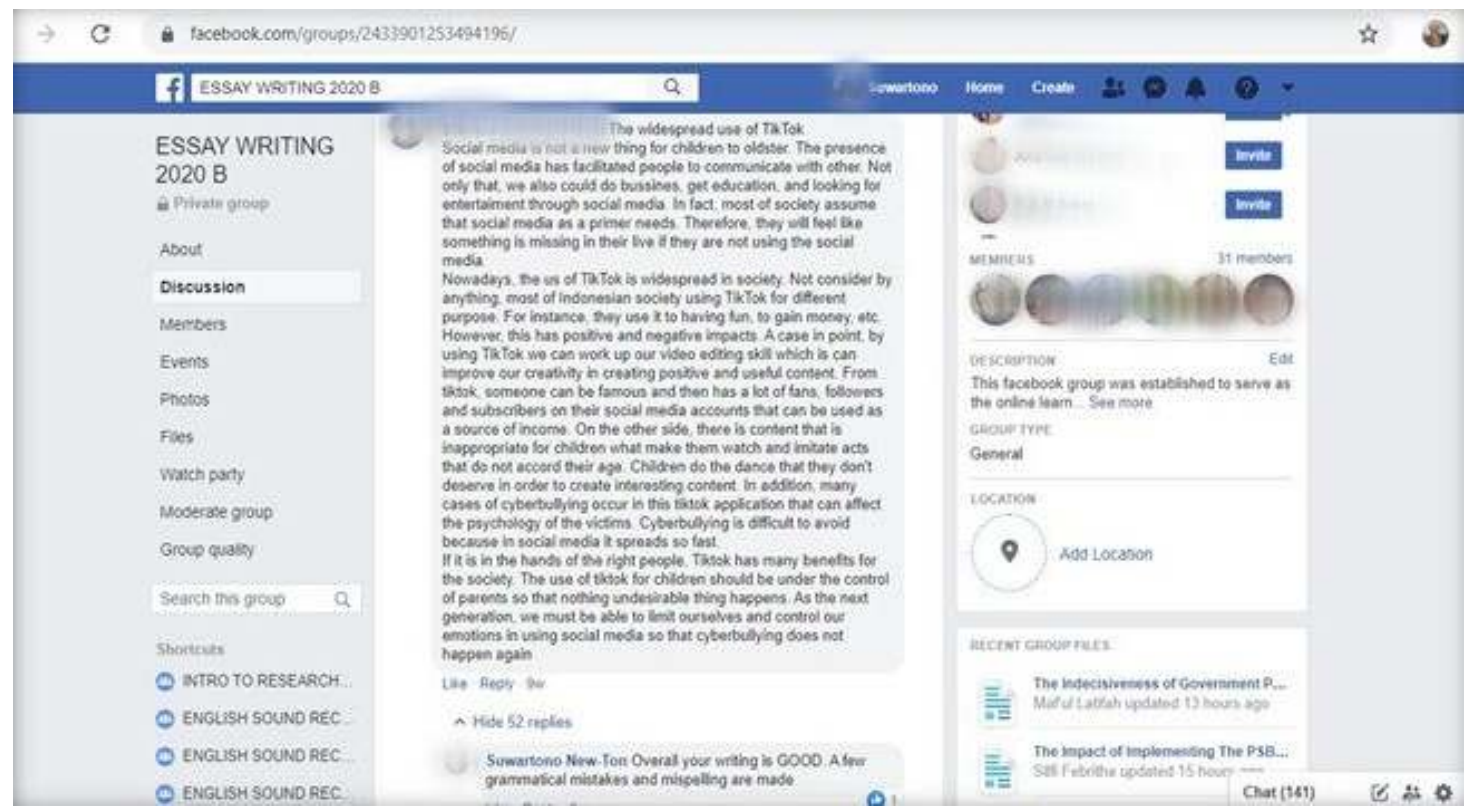

Figure 1. A Sample Student's Essay Work

Once a work of an essay writing was shared, all participants (group members) saw it there. In a second, students and or teachers in turn commented, asked for clarification, gave suggestions, etc. Quite often the teacher "stepped backward" monitoring and assessing them. They seemed to get involved in the learning and teaching process. A student reported:

“... FB Group helps me enough in learning how to write essay, because I can see details of friends' essay works and I can learn from them for revising my own work. In addition, inter-student discussion seems more vivid and can share suggestions to each other with regard to friends' works." (S10)

What they learnt and used throughout this learning covered either linguistic items or content. It is likely that the use of $\mathrm{FbG}$ in the essay writing course online had direct impact on student learning. The following short statement shows how a student experienced effective learning in the course.

“... Sometimes, I come across new vocabulary from reading and figuring out friends' essays. Also, I can learn a lot from feedback given by classmates, for example in regard to grammar. ..." (S11)

A highly reflective learning triggered by comparing student own work with those of others is apparent in the following:

From all friends' assignments submitted through the Group (FbG), I then compare them with mine. In such a way that I am thinking, oh in others like this, how come is mine like this... like this? ...then I am thinking how to arrange...what to present in the first, second until the last paragraph. I wonder if there is a rule..." (S23)

A variety of feedback covering comments, questions, and suggestions were addressed to the writer. Substantially, the discussion was information rich. Figure 2 shows a screenshot of a sample class discussion appearing on the $\mathrm{FbG}$. 
Suwartono. (2021). FbG as an around the clock support for an essay writing course amidst the pandemic. EduLite: Journal of English Education, Literature, and Culture, 6 (2), 238-255. http://dx.doi.org/10.30659/e.6.2.238-255

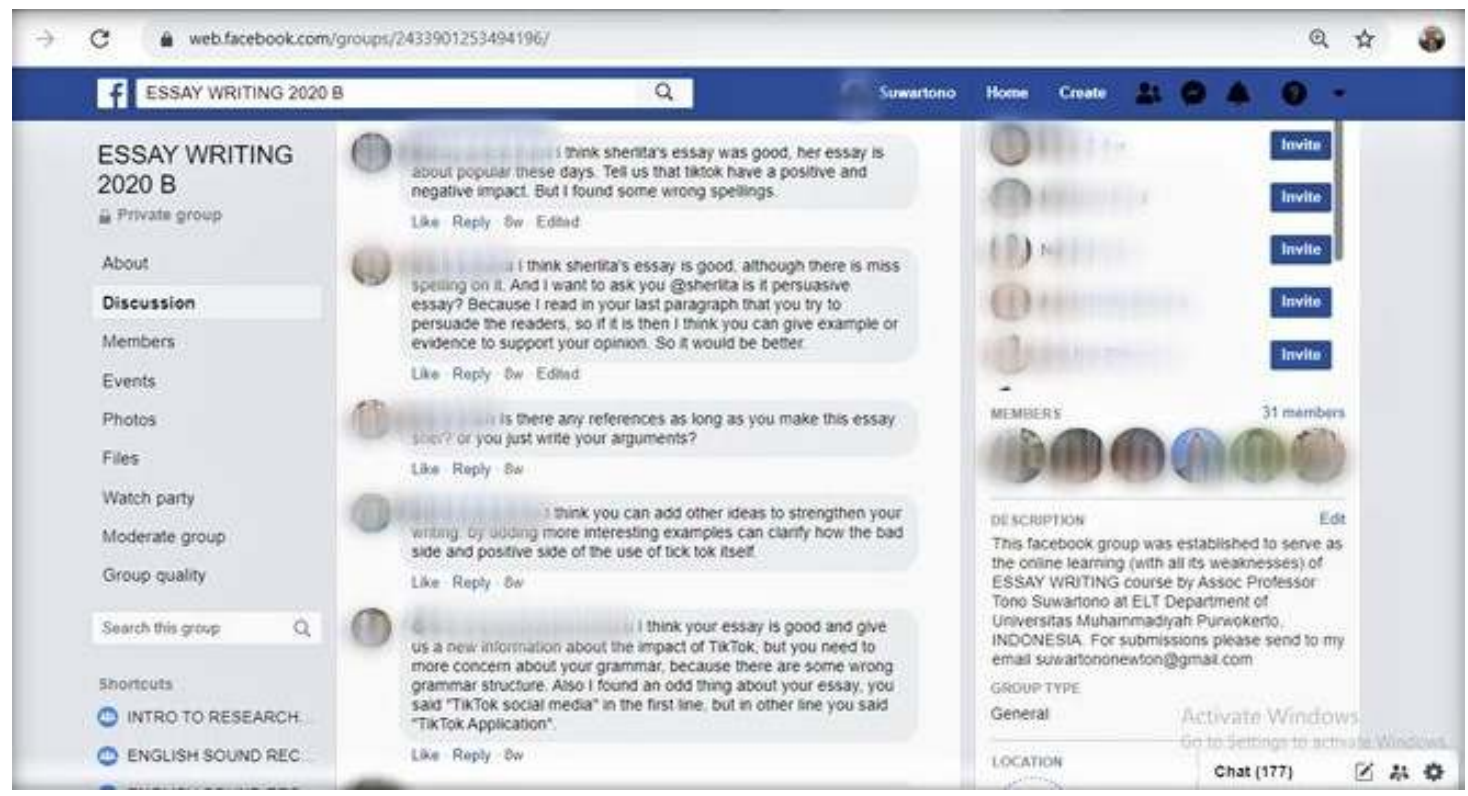

Figure 2. A Sample Discussion Forum

Beyond the screenshot coverage hundreds of discussion chats were made by class participants. They seemed to be enthusiastic and keen on asking for clarification, sharing ideas, and giving advice for betterment. Some highlighted content; others, however, paid more attention to language use or generic structure of the essay posted (see Figure 1 above). This discussion might turn into a serious end, so accordingly the teacher returned to lend a hand. Sometimes, a session of 100 minutes ended while the participants still seemed so busy discussing their topic of the day.

From interviews, the students also shared another good experience of learning essay with $\mathrm{FbG}$ as the online media. It has something to do with flexibility and practicality to access the shared learning materials as resources on FbG. Some statements have confirmed the data elicited through questionnaire. Here is a sample share of feeling from a student:

“..., In addition, Facebook Group records teaching and learning activities, so I can look into the activities that have gone by again" (S13)

In line with that, the following interview excerpts are quite similar:

“... materials and assignments are shared on Facebook Group. That enables me to study again the teaching and learning materials anytime I want ..." (S02)

“... I can study essay works and feedback repeatedly with no limit of time...." (S16)

"... easy to access, because it can help me when I need to reopen the materials that have been taught, so that I can study them again at any time later, ..." (S17)

It is particularly beneficial for helping students to develop independent learning, as repeated learning will enable learners understand and acquire 
learning materials better. This is very efficient as well, in that all materials and activities are kept in a single place, i.e., FbG site.

Above all, students had good learning experience with $\mathrm{FbG}$, due to its strength as part of leading technology. Here is an excerpt that shows how the FbG which they have become a member of excited them to learn at their best. A student highlighted its efficiency:

“...Facebook does not charge much data, so that it is more economical, Facebook is also a simple-to-access social media, by which learning can run well...” (S20)

It is apparent that the student referred to Facebook Group, which is a service offered within Facebook. In addition to efficiency, FbG benefitted them because of practicality, as commented by another student comparing it with another kind of social media:

“...for a review I like to scroll up on Facebook media to review a teaching and learning materials and activities. Different from WhatsApp, where to scroll up for a review seems boring because it looks full of texts and piled up like that, Sir." (S22)

The university has allowed the faculty members to select e-learning platforms during the pandemic. In the Department of English Language Teaching, where this study was conducted, at least 5 kinds of online media (Zoom, Schoology, E-mail, WhatsApp, and Facebook Group) have been chosen by the academic personnel as either single platform or a combination). FbG has started to become a favourite online platform among these students under investigation. Some data supported this trend, as explicitly aforementioned and reflected in the following:

“... If use of Facebook Group as essay learning media is continued, I will be more benefitted from it, as Facebook Group is not complicated." (S16)

This shows that to the student, FbG is impressive in term practicality. It was in line with the work of Dorrol et al. (2019) arguing that the social media tool is simple, familiar, and readily available. It was an easy-to-operate social media. It provided students with sense of authenticity.

All interview data, including those presented and discussed above were classified into four main categories of themes as follows.

Table 3. Benefits of FbG Usage According to Interview

\begin{tabular}{clcr}
\hline No & \multicolumn{1}{c}{ Benefits } & $\begin{array}{c}\text { No. of } \\
\text { Responses }\end{array}$ & $\begin{array}{c}\text { \% of } \\
\text { Total }\end{array}$ \\
\hline $\mathbf{1}$ & $\begin{array}{l}\text { FbG discussion feedback, comments, and replies } \\
\text { provided invaluable learning input }\end{array}$ & 13 & 30.2 \\
\hline $\mathbf{2}$ & FbG was simple to access or use & 13 & 30.2 \\
\hline $\mathbf{3}$ & FbG content was accessible at any time anywhere & 8 & 18.6 \\
\hline $\mathbf{4}$ & $\begin{array}{l}\text { Virtual participants on FbG brought convenience } \\
\text { and raised confidence to share ideas/thoughts }\end{array}$ & 7 & 16.3 \\
\hline $\mathbf{5}$ & Misc. & 2 & 4.6
\end{tabular}


Suwartono. (2021). FbG as an around the clock support for an essay writing course amidst the pandemic. EduLite: Journal of English Education, Literature, and Culture, 6 (2), 238-255. http://dx.doi.org/10.30659/e.6.2.238-255

As can be seen in the table, two equal biggest contributions of $\mathrm{FbG}$ according to interview results are: FbG facilitated directly to learning through discussion forum it offers and FbG was simple to access or use. Then, the third and fourth places are: FbG learning materials were accessible with no limit of time and virtual participants on FbG helped develop self-confidence to participate in learning.

When confronted to data obtained from the open questionnaires, data elicited through the interviews were partly consistent. First, data fell to four main categories of themes and one small portion of miscellaneous data. Two remained the same at their position, while the other two interchanged positions. The strongest and most impressive felt-benefit of $\mathrm{FbG}$ in the online essay writing course is that it facilitated learning. Students understood and acquired materials better than they did in traditional classroom learning prior to the pandemic. The second consistent data showing the strength of FbG was that FbG learning materials were accessible to students with no limit of time. They could return to and study the materials as many times as they want, as the content on FbG was open access to members around the clock. Therefore, FbG usage might support independent learning.

The other two findings obtained from questionnaire are 1) virtual participants on FbG helped develop self-confidence to participate in learning, and 2) FbG was simple to access or use. FbG usage psychologically affected student performance. The absence of students in person enabled them to perform better. In the meanwhile, FbG to many students was an effortless way to access. It was beneficial to them, as it was practical and efficient.

With regard to writing performance, from the weekly online learning and practice, it could be said that students' essay writing performance was good enough. There were not many serious mistakes made (see again Figure 1 for a sample). There were not many comments given by the teacher and peers. Comments addressed by peers generally dealt with content and some spelling and punctuation flaws, whereas comments given by the teacher generally referred to language use, especially grammatical problems.

Content in the internet is unlimited, and can be utilized for good things. To help ensure authenticity of students' writing process, in addition to regular real time writing activity during online class as scheduled, they were given an assignment nearly every other week. Once, they were assigned a detailed stepby-step writing process video making employing the thinking aloud technique. It seemed quite challenging. Students had to verbalize their thoughts while writing an essay. They had to spotlight every single stage from outlining, resourcing, drafting, revising, to finalizing. This procedure was taken as an endeavour to raise student integrity awareness (for example, danger of copypasting act, or being alert to plagiarism).

They were required to submit their videos by uploading them to Google Drive and sharing the link on the 'Comment' space on the FbG. Peers were invited to open the link and comment them. Feedback was also given by the teacher. It is very necessary to offer a good activity integrated to the selected online learning platform, $\mathrm{FbG}$, at least to boost power dynamics of the distance learning during the pandemic as "innovations unfolding under the heat of immediate necessity" (Barre, 2020). Figure 3 is a writing process video 
EduLite Journal of English Education, Literature, and Culture Vol. 6, No. 2, August 2021, pp. 238-255

E-ISSN: 2528-4479, P-ISSN: 2477-5304

http://jurnal.unissula.ac.id/index.php/edulite DOI: http://dx.doi.org/10.30659/e.6.2.238-255

print screen that demonstrated how a student wrote her essay in a detailed step-by-step process.

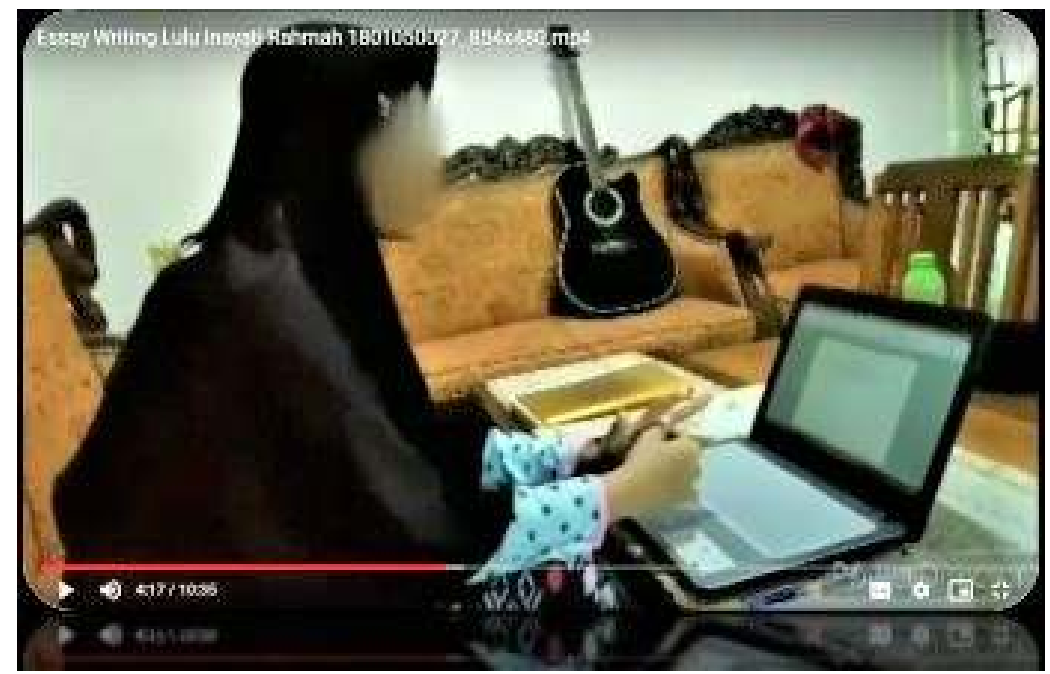

Figure 3. A sample video of student's essay writing process

As part of assignment series, the students' videos were rated. Feedback was given to each work available on 'the 'Reply' just under the link on the FbG. Out of eighty-seven registered students, seventy-one submitted their works. The rating showed an average score of 74.00 which, according to the university academic guideline, belongs to category 'Good' (70-74).

Combined with creative assignments students could do while accessing the materials 24 hours around the clock, they seemed excited and serious to complete in due time. A couple of weeks before the mid-semester test students were assigned to make an outline for an essay with predetermined topic. They were required to complete it on the 'Create Doc' feature available on the FbG. They could return to continue writing and editing (appeared as '.... edited a doc') at any time later. Figure 4 is a print screen of sample student's work, which whole members could also see anytime. 
Suwartono. (2021). FbG as an around the clock support for an essay writing course amidst the pandemic. EduLite: Journal of English Education, Literature, and Culture, 6 (2), 238-255.

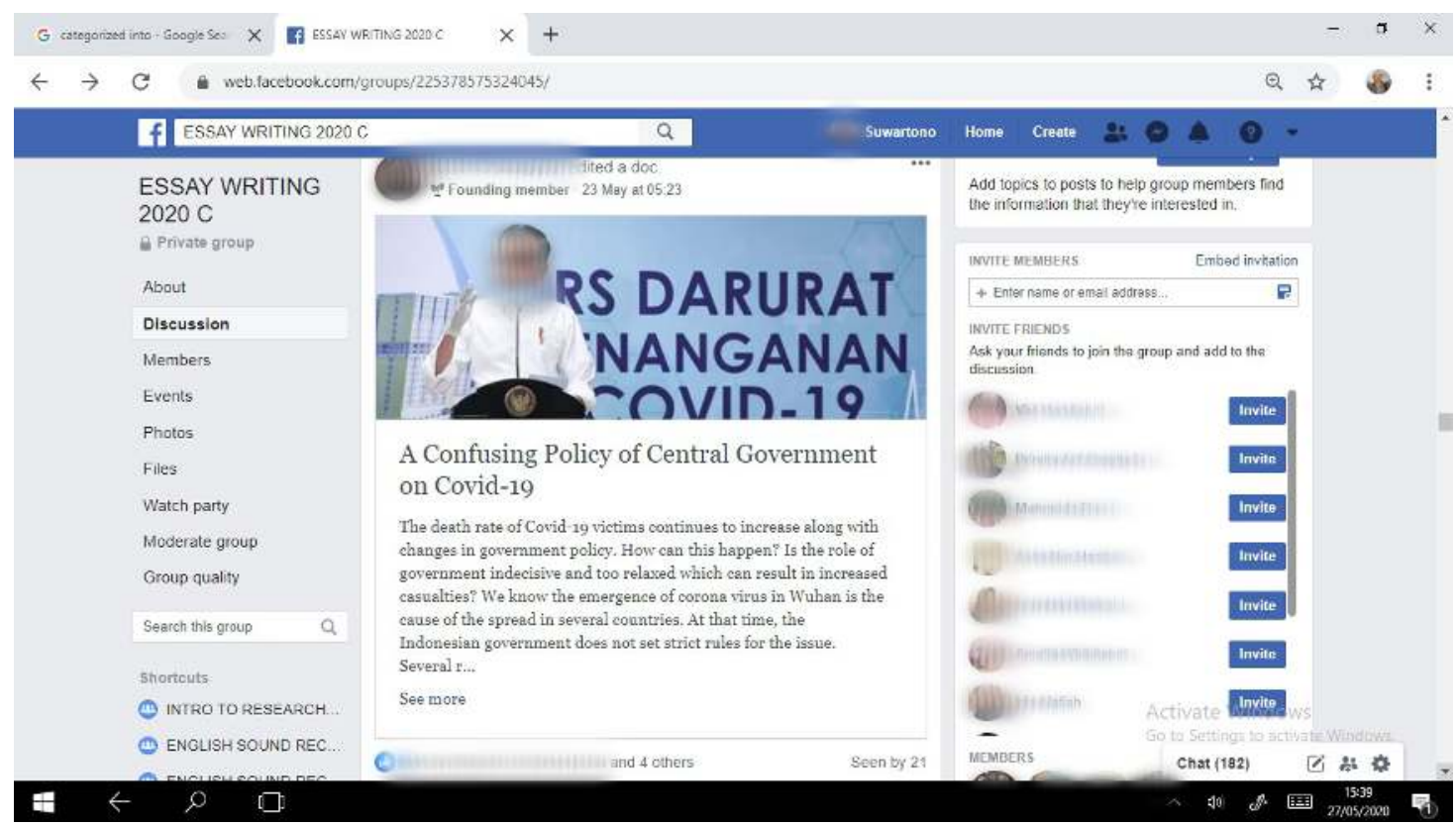

Figure 4. A sample student's essay in 'Create Doc' Professional Look

Students' excitement was seen from number of seers (bottom right), reactions (bottom left), and comments (below beyond coverage) on others' works. They really learned from each other. No wonder their writing ability progressed rapidly in spite of observed faults, mainly a few grammatical errors. Overall, other writing components were already good. This amenity available on FbG would have brought them a joyful learning and sense of accomplishment. They learnt to write English essay effortlessly and proudly due to professional, authentic look works, just like to say "Great, I can do it". From learning process point of view, this result tended to show acceptability in the part of students. Nevertheless, it is always necessary to examine its results for better acceptability worldwide (Reddy et al., 2020).

Good teaching and learning process seemed to have resulted in good learning outcome. Online mid-term test administered centrally by the university has shown that the students' essay writing performance reached an average score of 7.75 which, according to the university academic guideline book, belongs to level 'Very Good'.

\section{CONCLUSION}

Study findings indicated that FbG has been an appropriate place for learning and developing skills for an essay writing course in the period of social distancing during the covid-19 pandemic. Use of $\mathrm{FbG}$ as networking site has made possible an effective, efficient, and practical essay writing learning for four main reasons. First, FbG discussion forum provided invaluable learning input. Discussion forum directly has enhanced students' essay writing learning. Through discussion forum students learned from the teacher and friends of diverse knowledge and skills. From the materials shared and posted 
to the FbG they had chance to compare and self-correct their work. Secondly, FbG was easy to operate due to its simplicity, popularity and familiarity. Together with 24-hour availability of material and resources on $\mathrm{FbG}$, the students could learn independently at their own pace. Last, the absence of participants in person brought them convenience and raised confidence to better engage in learning online through FbG. FbG has fully supported students' essay writing learning process that has led to good writing performance despite the harsh condition amidst the pandemic. This can be seen not only from the conducive learning process in comparison to traditional classroom instruction prior to the pandemic, but also from learning outcome apparently observed in writing tasks, assignments, as well as mid-term test. The students' writing performance has reached more than expected.

\section{Recommendation}

No one study aforementioned in the review of literature is straight to the use of $\mathrm{FbG}$ in the context of essay writing course. This is how this study provides its biggest contribution. In the first place, teachers of English may consider FbG as their first-choice online media for teaching essay writing or other high order thinking writing skills. Researchers and creative English teachers are challenged to explore the potential of $\mathrm{FbG}$ in English language teaching, as many of the features on FbG have remained unexplored in the present study. For university students, besides using Facebook for communication media it is highly recommended that they utilize FbG for developing their essay writing skills.

With regard to methodology, this study highlights the importance of multi-data collection techniques as an effort to fine-tune data and, therefore, minimize threat of bias. Glancing at this study results of closed questionnaire alone might have taken us to a misleading conclusion. Once it was confronted to results of open questionnaire and interviews there was significant shift, let us say, from cool response to genuinely positive response, reflecting the students' actual experience learning essay writing with FbG implemented as online teaching and learning media during the pandemic.

\section{ACKNOWLEDGEMENTS}

The author is much indebted especially to Ayu Retno Cahyaningtyas, a fourth semester student, for her assistance during data collection and data analysis of this study. The authors also would like to express sincere thanks to all students who participated in the study for their warm and kind cooperation. 
Suwartono. (2021). FbG as an around the clock support for an essay writing course amidst the pandemic. EduLite: Journal of English Education, Literature, and Culture, 6 (2), 238-255.

\section{REFERENCES}

Alotumi, M. (2015). Innovation in English language teacher education. Facebook Interaction (FBI) and Essay Writing Pre-task: Yemeni EFL Students' Perceptions, Attitudes and Challenges. In G. Pickering \& P. Gunashekar (Eds.), Innovation in English language teacher education (pp. 125-133). British Council, India. https://dx.doi.org/10.2139/ssrn.3185696

Andini, M. (2019). Contribution of Facebook group in writing activity. Journal of EFL Research: The Academic Journal of Studies in English Language Teaching and Learning, 4(1), 44-51. https://doi.org/10.22236/JER_Vol4Issue1pp44-51

Aziz, Z. A., \& Khatimah, H. (2019). Enjoying learning writing through Facebook group. Lingua Cultura, 13(2), 115-119. https://dx.doi.org/10.21512/lc.v13i1.5513

Barre, B. (2020). Three strategies for teaching writing remotely during the pandemic. Center for the Advancement of Teaching. https://cat.wfu.edu/2020/04/writingstrategies/

Boukes, M. (2019). Social network sites and acquiring current affairs knowledge: The impact of twitter and Facebook usage on learning about the news. Journal of Information Technology \& Politics, 16(1), 36-51. https://doi.org/10.1080/19331681.2019.1572568

Dorrol, C., Hall, K., Blouke, C., \& Witsell, E. (2019). Virtual exchange pedagogy: A digital humanities approach. Journal of Comparative and International Higher Education, 9(11), 3-10. https://doi.org/10.32674/jcihe.v11iSpring.925

Faizi, R., Afia, A. E., \& Chiheb, R. (2013). Exploring the potential benefits of using social media in education. International Journal of Engineering Pedagogy, 3(4), 50-53. http://dx.doi.org/10.3991/ijep.v3i4.2836

Friatin, L. Y. (2018). Students' perception on teaching writing through Facebook group. VISION: Journal for Language and Foreign Language Learning, 7(1), 57-66. https://doi.org/10.21580/vjv7i12739

GlobalStats. (2020). Social media stats in Indonesia. - Retrieved April 2020 from https://gs.statcounter.com/social-media-stats/all/indonesia

Hamidah, F. N., \& Yanuarmawan, D. (2017). Using Facebook group in teaching writing of English for accounting classes. Advances in Social Sciences, Education and Humanities Research, 14, International Conference on English Language Teaching 2017, 302-307. https://dx.doi.org/10.2991/iconelt-17.2018.62

Imaniah, I., Zakky, A., \& Anggraini, D. R. (2020). Indonesia-Japan cross culture Facebook writing program: new challenges in teaching writing. The Asian EFL Journal, 27(5.2), 23-35.

Jacques, S., Quahabi, A., \& Lequeu, T. (2020). Remote knowledge acquisition and assessment during the COVID-19 pandemic. International Journal of Engineering Pedagogy, 10(6), 120-138. https://doi.org/10.3991/ijep.v10i6.16205

Kallas, P. (2019). Top 15 most popular social networking sites and apps [2020]. Retrieved September 2, 2019 (updated April 9, 2020) from https://www.dreamgrow.com/top-15-most-popular-social-networking-sites /

Kent, M. (2014). What's on our mind? Facebook as a forum for learning and teaching in higher education. In M. Kent and T. Leaver (Eds.), An education in Facebook? Higher education and the world's largest social network, (pp. 53-60). Taylor \& Francis. 
Edulite Journal of English Education, Literature, and Culture

Vol. 6, No. 2, August 2021, pp. 238-255

E-ISSN: 2528-4479, P-ISSN: 2477-5304

http://jurnal.unissula.ac.id/index.php/edulite DOI: http://dx.doi.org/10.30659/e.6.2.238-255

Li, V. (2017). Social media in English language teaching and learning. International Journal of Learning and Teaching, 3(2), 148-153. https://doi.org/10.18178/ijlt.3.2.148-153

Manca, S., \& Ranieri, M. (2014). Does Facebook provide educational value? An overview of theoretical and empirical advancements of affordances and critical issues. In G. Mallia (Ed.), The social classroom: Integrating social network use in education, (pp. 311-330). Information Science Reference (IGI Global).

Ngai, P. B. (2019). Online social networking transnational-competence development among international students from Japan. Journal of International Students, 9(2), 432-459. https://doi.org/10.32674/jis.v9i2.607

Ping, N. S., \& Maniam, M. (2015). The effectiveness of Facebook group discussion on writing performance: a study in Matriculation College. International Journal of Evaluation \& Research in Education, 4(1), 30-37. https://files.eric.ed.gov/fulltext/EJ1091701.pdf

Ramadhani, P. (2018). Using Facebook comments in teaching writing skill. Proceedings of the ICECRS, 1(3), National Seminar FKIP UMSIDA, Sidoarjo. https://doi.org/10.21070/picecrs.v1i3.1398

Reddy, R., Singh, R., \& Kapoor, V. (2020). Joy of learning through internet memes. International Journal of Engineering Pedagogy, 10(5), 116-133. https://doi.org/10.3991/ijep.v10i5.15211

Rodliyah, R. S. (2016). Using a Facebook closed group to improve EFL students' writing. TEFLIN Journal, 27(1), 82-100. http://dx.doi.org/10.15639/teflinjournal.v27i1/82-100

Saddhono, K., Hasibuan, A., \& Bakhtiar, M. I. (2019). Facebook as a learning media in TISOL (Teaching Indonesian to Speakers of Other Languages in Indonesia) learning to support the independency of foreign students in Indonesia. $1^{\text {st }} U P Y$ International Conference on Applied Science and Education, 1-6. http://dx.doi.org/10.1088/1742-6596/1254/1/012061

Sirivedin, P, Soopunyo, W., Srisuantang, S., \& Wongsothorn, A. (2018). Effects of Facebook usage on English learning behavior of Thai English teachers. Kasetsart $\begin{array}{lllll}\text { Journal of Social } & \text { Sciences, } & 39, & 183-189 .\end{array}$ http://dx.doi.org/10.1016/j.kjss.2018.03.007

Sulisworo, D., Rahayu, T., \& Akhsan, R. N. (2016). The students' academic writing skill after implementing blended learning using Facebook. Information Technologies and Learning Tools, 56(6), 176-189. https://doi.org/10.33407/itlt.v56i6.1477

Suwartono, T., \& Mayaratri, P. (2011). Handling the EFL students' crisis of selfconfidence to ask questions. Sino-US English, 8(1), 24-31. http://www.davidpublisher.org/Public/uploads/Contribute/55a5f6eb4f808.pdf

Syafrial, Rumadi, H., \& Fatimah, R. P. S. N. (2019). The empowerment of Facebook in language learning at the university. Asian EFL Journal, 25(5), 43-61. https://www.asian-efl-journal.com/wp-content/uploads/AEJ-VOL.25-ISSUE5.1-OCTOBER-2019.pdf

Tananuraksakul, N. (2015). An investigation into the impact of Facebook group usage on students' affect in language learning in a Thai context. International Journal of Teaching and Learning in Higher Education, 27(2), 235-246. https:// files.eric.ed.gov/fulltext/EJ1082882.pdf 
Suwartono. (2021). FbG as an around the clock support for an essay writing course amidst the pandemic. EduLite: Journal of English Education, Literature, and Culture, 6 (2), 238-255.

Toker, S., \& Baturay, M. H. (2019). What foresees college students' tendency to use Facebook for diverse educational purposes? International Journal of Educational Technology in Higher Education, 16(9), 1-20. https://educationaltechnologyjournal.springeropen.com/articles/10.1186/s412 39-019-0139-0\#Sec7

Wope, M. \& Belle, J. V. (2018). Using Facebook by first year university students to adjust to the tertiary environment. Proceedings of the $13^{\text {th }}$ International Conference on e-Learning, Cape Peninsula University of Technology, Cape Town, South Africa, 551-560.

Yunus, M. M. D., Salehi, H., Sun, C. H., Yen, J. Y. P., \& Li, L. K. S. (2011). Using Facebook groups in teaching ESL writing. Recent Researches in Chemistry, Biology, Environment and Culture, 75-80. http://wseas.us/elibrary/conferences/2011/Montreux/COMICICBIO/COMICICBIO-11.pdf

Conflict of Interest Statement: The authors declare that the research was conducted in the absence of any commercial or financial relationships that could be construed as a potential conflict of interest.

Copyright (C) 2021 Suwartono. This is an open-access article distributed under the terms of the Creative Commons Attribution License (CC BY). The use, distribution or reproduction in other forums is permitted, provided the original author(s) and the copyright owner(s) are credited and that the original publication in this journal is cited, in accordance with accepted academic practice. No use, distribution or reproduction is permitted which does not comply with these terms. 